\title{
PENERAPAN PRINSIP-PRINSIP HAZARD ANALYSIS CRITICAL CONTROL POINT (HACCP) DALAM PENYELENGGARAAN MAKANAN LAUK HEWANI DI INSTALASI GIZI RSUD PROF. DR. MARGONO SOEKARJO PURWOKERTO
}

\author{
The Implementation Of Hazard Analysis Critical \\ Control Point (HACCP) Principles On Food Service Of Animal Side Dishes In \\ Nutritional Installation Of RSUD Prof. Dr. Margono Soekarjo Purwokerto
}

\author{
Annisya Fauzia ${ }^{1}$, Friska Citra Agustia $^{2}$, Nurrekta Yuristianti ${ }^{3}$ \\ ${ }^{1}$ Ilmu Gizi Universitas Jenderal Soedirman \\ ${ }^{2}$ Bagian Kesehatan Masyarakat Universitas Jenderal Soedirman \\ ${ }^{3}$ Bagian Gizi Institusi Universitas Jenderal Soedirman
}

Email: Annisyaf9@gmail.com

\begin{abstract}
The purpose of this research is to know implementation of HACCP priciples on animal side dishes food process in nutritional installation of RSUD Prof. Dr. Margono Soekarjo Purwokerto. This research uses observational qualitative approach with descriptive method. The data collection is conducted through semi-structured interview, observation of moderate participation and document analysis. The informants are chosen by using purposive sampling which is based on inclusion and exclusion criteria. Observation is conducted toward the processing of 4 kinds of animal side dishes. The data obtained are analyzed by reducing the data, displaying the data and drawing the conclusion. The risk identification in the processing of animal side dishes is conducted toward microbiological, chemical and physical hazards. The determination of CCP is done by using Codex Decission Tree. The determination of critical limit for each CCP is performed by arranging stages which include CCP then compiling parameters and critical limit of each parameter. The system verification is done by monitoring the final products regularly and conducting. laboratory test on the final products. The corrective action is arranged based on the risk level. The recording and documentation of HACCP have not covered all kinds of animal side dishes on ten-day cycle menu in Nutritional Installation of RSUD Prof. Dr. Margono Soekarjo.
\end{abstract}

Keywords: HACCP, Animal Side Dishes, Food Service.

\begin{abstract}
ABSTRAK
Tujuan penelitian adalah untuk mengetahui penerapan HACCP priciples pada proses makanan lauk pauk pada instalasi gizi RSUD Prof. Dr. Margono Soekarjo Purwokerto. Penelitian ini menggunakan pendekatan kualitatif observasional dengan metode deskriptif. Pengumpulan data dilakukan melalui wawancara semiterstruktur, observasi partisipasi moderat dan analisis dokumen. Informan dipilih dengan menggunakan purposive sampling yang didasarkan pada kriteria inklusi dan eksklusi. Pengamatan dilakukan terhadap pengolahan 4 jenis lauk pauk hewani. Data yang diperoleh dianalisis dengan mengurangi data, menampilkan data dan menarik kesimpulan. Identifikasi risiko dalam pengolahan lauk pauk hewan dilakukan terhadap bahaya mikrobiologi, kimia, dan fisik. Penentuan CCP dilakukan dengan menggunakan Codex Decission Tree. Penentuan batas kritis untuk masing-masing CCP dilakukan dengan mengatur tahapan yang mencakup CCP kemudian menyusun parameter dan batas kritis dari setiap parameter. Verifikasi sistem dilakukan dengan memantau produk akhir secara teratur dan melakukan. Uji laboratorium pada produk akhir. Tindakan korektif disusun berdasarkan tingkat risiko. Rekaman dan dokumentasi HACCP belum mencakup semua jenis lauk pauk pada menu siklus sepuluh hari di Instalasi Nutrisi RSUD Prof Dr Margono Soekarjo.
\end{abstract}

Kata kunci: HACCP, Layanan Makanan 


\section{PENDAHULUAN}

Penyelenggaraan makanan di rumah sakit lebih bersifat kompleks. Risiko terjadinya kontaminasi silang di rumah sakit jauh lebih besar karena banyaknya hidangan yang dimasak atau disiapkan secara bersamaan (Jusniati et al., 2012). Pada saat makanan disajikan untuk banyak orang, sejumlah besar makanan telah dipersiapkan berjam - jam bahkan lebih dari sehari untuk mendukung pelayanan yang cepat. Jika selama selang waktu antara penyiapan dan penyajian makanan tersebut tidak disimpan pada kondisi yang dapat mencegah pertumbuhan mikroba maka bahaya akan terbentuk (Djarismawati et al., 2010).

Tujuan akhir dari penyelenggaraan makanan di rumah sakit adalah tersedianya makanan yang baik dari segi kualitas dan kuantitasnya untuk konsumen atau pasien (Maria, 2004). Salah satu komponen makanan tersebut adalah lauk hewani. Lauk hewani merupakan salah satu komponen menu yang dapat divariasikan dan memberikan sumbangan zat gizi terutama protein dalam satu satuan menu yang disajikan kepada pasien (Nene, 2012). Puspita et al. (2010) menyatakan bahan pangan hewani merupakan sumber utama bakteri penyebab infeksi dan intoksikasi serta rentan mengalami kontaminasi oleh bahaya fisik, biologi, maupun kimia.
Jusniati et al. (2012) menyatakan untuk dapat menyediakan makanan berkualitas yang bebas dari kontaminasi bahaya-bahaya mikrobiologi, fisik dan kimia, Hazard Analysis Critical Control Point (HACCP) menjadi salah satu sistem yang penting dalam meminimalisir risiko yang dapat timbul dari pengolahan makanan khususnya di rumah sakit. Menurut SNI HACCP (1998), HACCP adalah suatu piranti untuk menilai bahaya dan menetapkan sistem pengendalian yang memfokuskan pada pencegahan dari pada mengandalkan sebagian besar pengujian produk akhir.

Beberapa penelitian tentang HACCP di rumah sakit telah dilakukan, antara lain observasi di unit gizi RSI Lumajang Tahun 2007 menunjukkan adanya kekurangan pada penerapan prinsip-prinsip HACCP pada makanan pokok pasien rawat inap dan praktik higiene sanitasi oleh penjamah makanan (Zulfana dan Sudarmadji, 2011). Hasil penelitian Damanik (2012) analisis terhadap penerapan prinsip-prinsip HACCP di Instalasi Gizi RSPAD Gatot Soebroto Jakarta Tahun 2012 sudah cukup baik. Hasil penelitian Puspita (2010) adanya pengaruh penerapan HACCP terhadap penurunan bahaya mikrobiologis pada makanan khusus anak berbasis hewani 
di Rumah Sakit Umum Daerah Dr. Soedarso Pontianak.

Berdasarkan data Profil Kesehatan Kabupaten Banyumas Tahun 2014 jumlah rumah sakit yang terdapat di Kabupaten Banyumas sebanyak 22 rumah sakit dan tiga diantaranya merupakan Rumah Sakit Umum Daerah (RSUD) yaitu RSUD Prof. Dr. Margono Soekarjo, RSUD Banyumas, dan RSUD Ajibarang. Dari tiga RSUD tersebut salah satunya adalah milik Pemerintah Provinsi Jawa Tengah yaitu RSUD Prof. Dr. Margono Soekarjo Purwokerto yang merupakan RSUD kelas B Pendidikan denganjangkauan pelayanan untuk masyarakat di wilayah Jawa Tengah bagian barat-selatan dan digunakan sebagai rumah sakit rujukan Tingkat Provinsi. Hal tersebut memungkinkan penyelenggaraan makanan rumah sakit yang lebih kompleks karena banyaknya kasus diit yang ditangani. RSUD Prof. Dr. Margono Soekarjo Purwokerto telah menerapkan HACCP sebagai sistem keamanan penyelenggaraan makanan dan membentuk tim khusus dalam pelaksanaannya. Berdasarkan latar belakang tersebut, maka penulis tertarik untuk mengetahui penerapan prinsipprinsip HACCP pada pengolahan lauk hewani dalam penyelenggaraan makanan di Instalasi Gizi RSUD Prof. Dr. Margono Soekarjo.

\section{METODOLOGI}

Penelitian ini menggunakan pendekatan kualitatif observasional dengan metode deskriptif. Pengumpulan data dilakukan dengan wawancara semiterstruktur, observasi partisipasi moderat dan telaah dokumen. Pemilihan informan dilakukan dengan purposive sampling yaitu berdasarkan kriteria inklusi dan ekslusi, didapatkan empat orang sebagai informan utama dan empat orang informan pendukung. Data yang didapat, dianalisis dengan cara reduksi data, display data dan penarikan kesimpulan.

\section{HASIL}

\section{Gambaran Umum Instalasi Gizi} RSUD Prof. Dr. Margono Soekarjo

Salah satu unit pelayanan RSUD Prof. Dr. Margono Soekarjo adalah Instalasi Gizi. Tujuan penyelenggaraan makanan Instalasi Gizi RSUD Prof. Dr. Margono Soekarjo yaitu tersedianya makanan yang tepat untuk pasien rawat inap. Tepat disini meliputi tepat citarasa, tepat waktu, tepat jumlah, tepat gizi, dan tepat sanitasi.

Penyelenggaraan makanan di Instalasi Gizi RSUD Prof. Dr. Margono Soekarjo menggunakan sistem swakelola, dimana semua makanan pasien dimasak langsung di dapur instalasi. Instalasi Gizi 
RSUD Prof. Dr. Margono Soekarjo menyusun tiga jenis siklus menu pasien yaitu siklus menu Makanan Saring Kelas I, II, dan III; siklus menu Nasi/Lunak/Diit Kelas I, II, dan III; serta siklus menu Paviliun Abiyasa, yang semuanya merupakan siklus menu 10 hari dan penambahan 1 menu untuk tanggal

Pendistribusian makanan kepada pasien menggunakan sistem sentralisasi, dimana semua makanan diolah di dapur utama dan didistribusikan langsung dari dapur utama.

\section{Gambaran Umum Hasil Penelitian}

\section{Identifikasi Bahaya atau Hazard} (Prinsip 1)

Diagram alir pengolahan lauk hewani disusun oleh tim, mulai dari tahap penerimaan bahan sampai distribusi, namun belum semua lauk hewani mempunyai digramalir pengolahan.

Identifikasi bahaya dilakukan terhadap bahaya mikrobiologi, kimia dan fisik. Dilakukan dengan uji laboratorium oleh IPLRS (Instalasi Pemeliharaan Lingkungan Rumah Sakit) setiap bulan dan Pemerintah Kabupaten dua kali dalam satu tahun, penyusunan daftar bahaya yang potensial mencemari, penyusunan spesifikasi bahan makanan, pemeriksaan bahan makanan sesuai spesifikasi, dan pengontrolan kelengkapan APD penjamah makanan.

\section{Penentuan CCP atau TKK (Titik Kendali Kritis) (Prinsip 2)}

CCP ditentukan oleh tim menggunakan Diagram Pohon Keputusan, terdapat dua jenis Diagram Pohon Keputusan yang digunakan yaitu Diagram Pohon Keputusan Proses dan Diagram Pohon Keputusan untuk Bahan Mentah. Berikut contoh Diagram Pohon Keputusan yang digunakan:

P1. Apakah bahan mentah memungkinkan mengandung bahan berhaya (mikrobiologi, fisik dan kimia)?

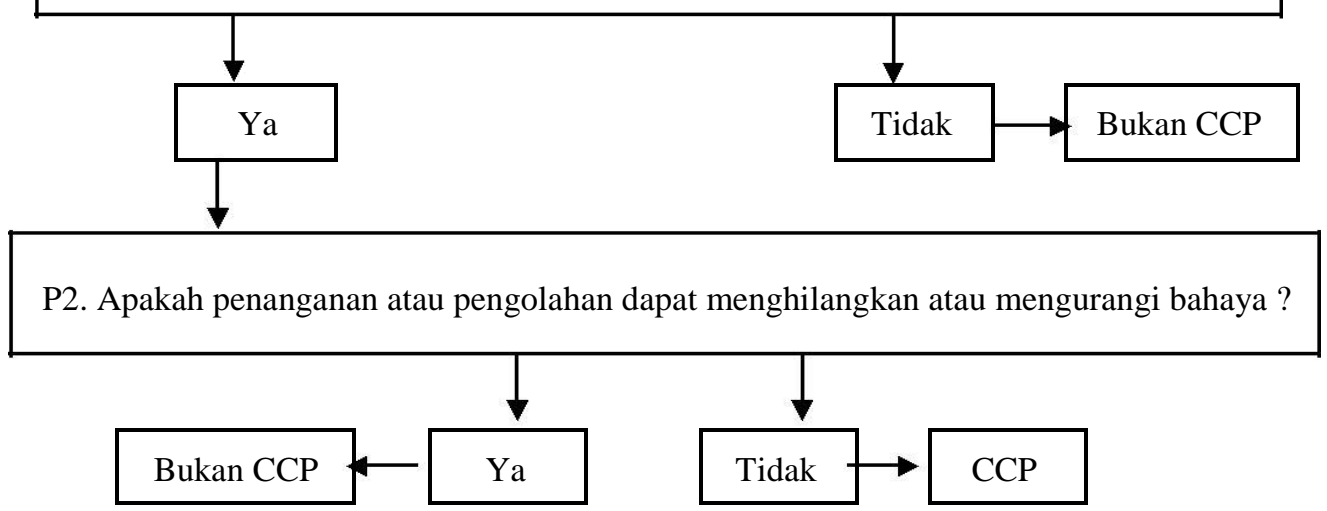

Gambar 1. Diagram Pohon Keputusan Bahan Mentah

Sumber : Pedoman HACCP Instalasi Gizi RSUD Prof. Dr. Margono Soekarjo 


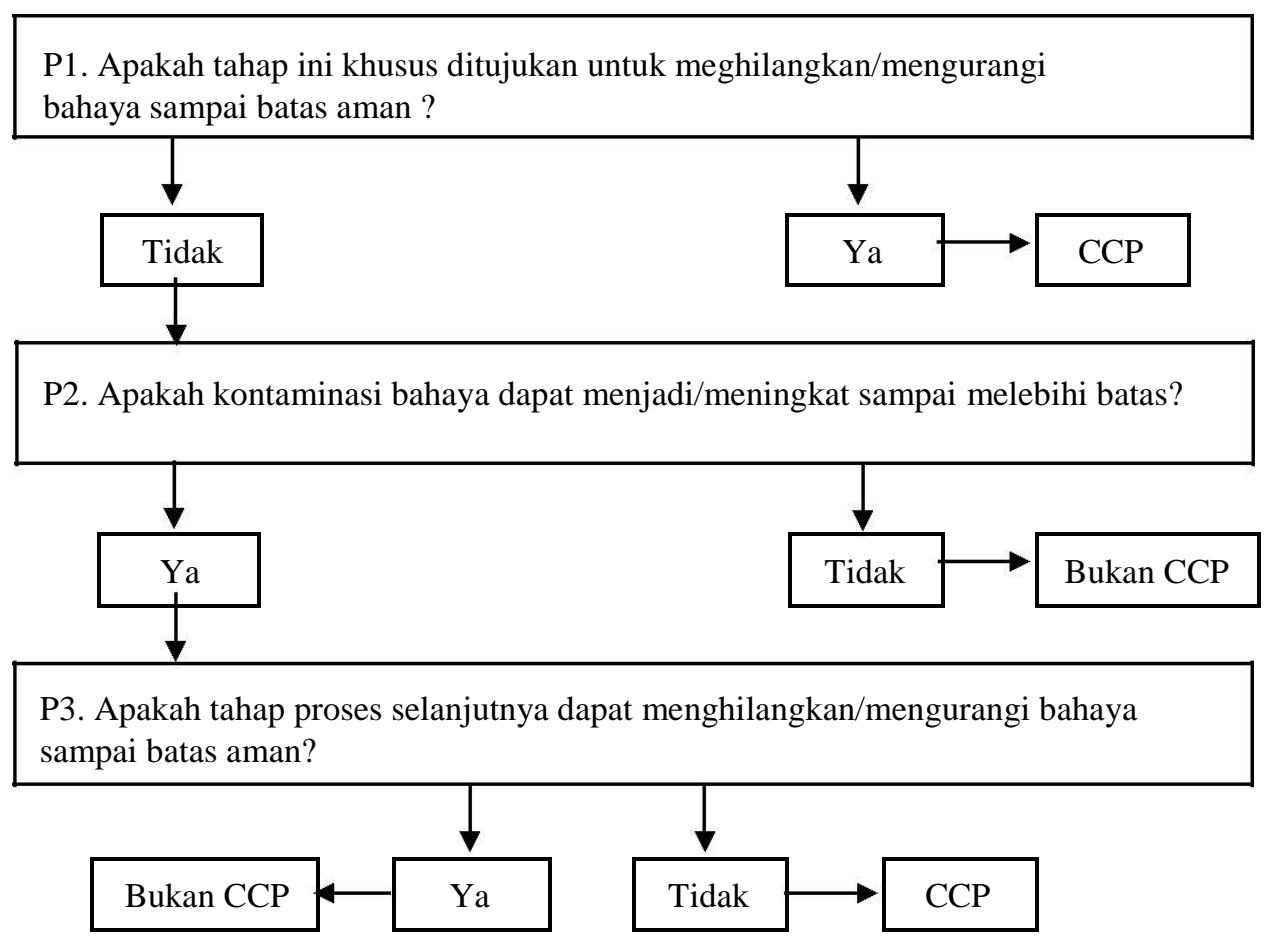

\section{Gambar 2. Diagram Pohon Keputusan Proses}

Sumber : Pedoman HACCP Instalasi Gizi RSUD Prof. Dr. Margono Soekarjo (2007)

\section{Spesifikasi Batas Kritis (Prinsip 3)}

Tim HACCP menentukan batas kritis pada setiap CCP dalam proses pengolahan lauk hewani dengan cara menyusun setiap tahap yang termasuk CCP kemudian menentukan parameter pengukuran setiap CCP. Tim HACCP juga memastikan bahwa batas kritis yang disusun untuk setiap CCP dalam pengolahan lauk hewani dapat mencegah bahaya, dibuktikan dengan hasil uji laboratorium terhadap bahan makanan dan produk akhir lauk hewani yang aman dikonsumsi.

\section{Penetapan dan Pelaksanaan Sistem}

\section{Monitoring (Prinsip 4)}

Monitoring dilakukan setiap hari pada setiap proses oleh penanggung jawab setiap bagian. Informan utama juga memberikan keterangan bahwa belum pernah ada kejadian prosedur pengolahan lauk hewani tidak dilakukan secara konsisten dan memastikan bahwa frekuensi monitoring sudah cukup untuk memastikan pengolahan lauk hewani berjalan dengan baik.

\section{Penetapan Tindakan Koreksi (Prinsip 5) \\ Penyusunan rencana tindakan} koreksi dilakukan oleh tim, namun belum ada pencatatan tentang tindakan koreksi 
yang pernah dilakukan. Berikut rencana tindakan koreksi yang disusun:

Tabel 1. Tingkat Resiko Bahaya Produk dan Tindakan Koreksi

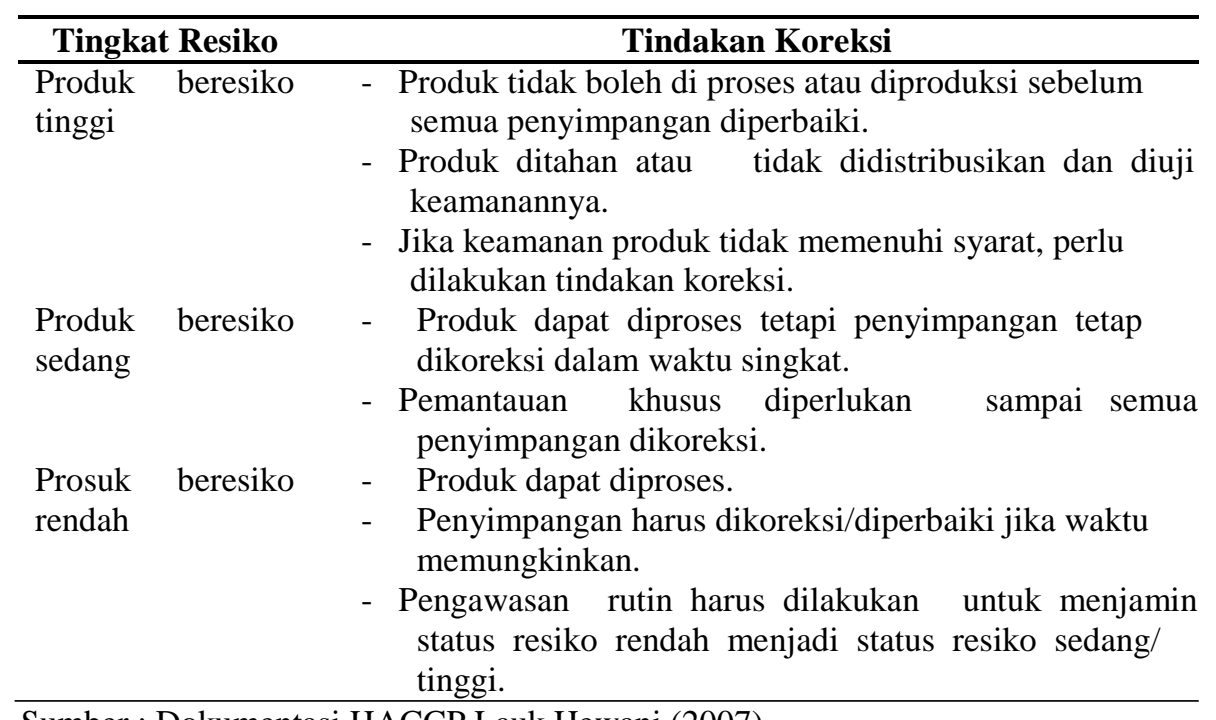

Sumber : Dokumentasi HACCP Lauk Hewani (2007)

\section{Penyusunan Prosedur Verifikasi \\ dokumentasi HACCP. Pendokumentasian (Prinsip 6) \\ Kegiatan verifikasi mencakup yang dilakukan mencakup seluruh prinsip HACCP.}

seluruh proses pengolahan lauk hewani. Berdasarkan hasil telaah dokumen

\section{PEMBAHASAN}

HACCP, belum adanya dokumen mengenai Instalasi Gizi RSUD Prof. Dr. prosedur tertulis mengenai verifikasi sistem HACCP pada pengolahan lauk hewani.

\section{Pencatatan dann Dokumentasi (Prinsip 7)}

Berdasarkan hasil telaah dokumen catatan dan dokumentasi HACCP dalam penyelenggaraan makanan lauk hewani di Instalasi Gizi RSUD Prof. Dr. Margono Soekarjo berupa hard file dan soft file. Dari total 67 jenis olahan lauk hewani dalam siklus menu 10 hari untuk pasien kelas I, II dan III dengan jenis Makanan Biasa, Makanan Lunak dan Diit, empat diantaranya belum mempunyai Margono Soekarjo membentuk tim khusus sebagai penyusun dan penanggung jawab sistem HACCP. Tim HACCP terdiri dari Kepala Instalasi Gizi, Penanggung Jawab Mutu, Penanggung Jawab Pengadaan/Produksi, dan Penanggung Jawab Logistik. Hayes dan Forsythie (2014) menjelaskan bahwa membentuk tim HACCP harus melibatkan semua komponen yang terlibat dalam penyelenggaraan dan produksi makanan di rumah sakit. Penerapan sistem HACCP sebagai sistem kemanan dalam pengolahan makanan khususnya lauk hewani di 
Instalasi Gizi RSUD Prof. Dr. Margono Soekarjo mengacu pada prinsip-prinsip HACCP yang terdapat dalam SNI HACCP Tahun 1998.

Identifikasi bahaya dalam sistem HACCP dapat dilakukan dengan pembuatan diagram alir terlebih dahulu (Thaheer, 2005). Diagram alir yang disusun oleh Tim HACCP mencakup setiap tahapan proses pengolahan mulai dari penerimaan bahan makanan sampai dengan pendistribusian, dilengkapi dengan keterangan tempat, suhu dan waktu.

Hal tersebut sesuai dengan yang dikemukakan Puspita et al. (2010) bahwa diagram alir harus memuat seluruh proses kegiatan dalam operasional produksi, diagram ini harus memuat rincian teknis yang memadai untuk anggota tim sehingga mereka dapat mengikuti setiap langkah dengan mudah. Identifikasi bahaya mikrobiologi dan kimia juga dilakukan dengan uji laboratorium terhadap keberadaan mikrobiologi dan bahan pengawet yang potensial mencemari. Petugas laboratorium mengambil langsung sampel bahan makanan, air, produk akhir, dan alat masak. Pemeriksaan juga dilakukan terhadap kesehatan tenaga penjamah makanan dengan pengambilan urin dan darah.

Penentuan CCP merupakan langkah selanjutnya setelah identifikasi bahaya. Penentuan CCP dilakukan oleh tim dengan menggunakan Diagram Pohon Keputusan atau Codex Decission Tree yang mengacu pada SNI HACCP 1998. CCP ditentukan pada bahan makanan mentah dan proses pengolahan. Seperti pada Gambar 1, penentuan CCP pada bahan mentah dimulai dengan menyusun bahan mentah yang digunakan kemudian masuk ke pertanyaan pertama (P1), jika jawabannya "Tidak" maka dapat dinyatakan bukan sebagai CCP atau bahan tersebut kemungkinan tidak mengandung bahaya. Tetapi, jika jawaban pada P1 adalah "Ya" maka dilanjutkan ke pertanyaan kedua (P2), jika jawaban pada P2 adalah "Tidak" maka dapat dinyatakan sebagai CCP yang berarti bahan mentah tersebut perlu pengawasan yang baik agar tidak menimbulkan ketidakamanan. Cara penentuan tersebut sama hal nya dalam penentuan CCP pada Diagram Pohon Keputusan Proses.

Setelah menetapkan CCP, dilakukan penentuan batas kritis untuk setiap CCP. Puckett (2004) mengemukakan bahwa batas kritis ditetapkan untuk menjamin bahwa CCP dapat dikendalikan dengan baik. Proses penentuan batas kritis ini dilakukan oleh tim HACCP dimulai dengan menyusun proses pengolahan yang termasuk CCP, kemudian menentukan parameter setiap proses tersebut dan 
membuat batas kritis untuk setiap parameter. Dalam dokumen HACCP lauk hewani yang ada di Instalasi Gizi, penetapan batas kritis pada CCP pengolahan lauk hewani fokus pada tempat penyimpanan, suhu tempat penyimpanan, suhu pemasakan dan waktu pemasakan serta waktu tunggu.

Kegiatan monitoring dilakukan setiap hari baik oleh penanggung jawab bagian atau oleh kepala instalasi. Setiap tahap dalam penyelenggaraan makanan di Instalasi Gizi mulai dari petugas logistik yang melakukan pemeriksaan terhadap bahan makanan yang datang dan mengatur penyimpanan bahan makanan, pengolah makanan dan bagian distribusi, memiliki penanggung jawab tersendiri. Rauf (2013) menjelaskan bahwa kegiatan pemantauan atau monitoring dapat berupa pengamatan yang direkam dalam suatu checklist ataupun merupakan suatu pengukuran yang direkam ke dalam suatu datasheet. Berdasarkan hasil telaah dokumen, instalasi telah mempunyai form checklist khusus untuk kegiatan monitoring harian karena kegiatan monitoring telah menjadi agenda rutin penanggung jawab tiap proses produksi.

Langkah selanjutnya adalah penetapan tindakan koreksi, Ratna (2009) mengemukakan bahwa tindakan koreksi dilakukan apabila terjadi penyimpangan terhadap batas kritis suatu CCP. Tim HACCP menyusun tindakan koreksi dimulai dengan mengelompokkan produk menjadi tiga tingkatan, kemudian setiap tingkatan ditentukan tindakan koreksinya. Seperti yang dijelaskan dalam Thaheer (2005) bahwa tindakan koreksi yang dilakukan jika terjadi penyimpangan sangat tergantung pada tingkat resiko produk pangan. Lauk hewani termasuk dalam kategori resiko tinggi, Cahyadi (2011) mengemukakan bahwa salah satu jenis produk resiko tinggi adalah daging sapi, daging ayam, daging kambing dan ikan serta produk olahannya.

Monitoring rutin dan uji laboratorium merupakan bentuk kegiatan verifikasi yang dilakukan oleh tim HACCP di Instalasi Gizi RSUD Prof. Dr. Margono Soekarjo. Dalam SNI HACCP (1998) dijelaskan bahwa ada beberapa kegiatan verifikasi yang dapat dilakukan yaitu penetapan jadwal HACCP, pemeriksaan kembali rencana HACCP, pengamatan visual selama produksi serta pengambilan contoh dan analisis secara random. Penyimpanan catatan dan dokumentasi merupakan langkah terakhir dalam sistem HACCP. Catatan dan dokumentasi HACCP pada lauk hewani dalam penyelenggaraan makanan di Instalasi Gizi RSUD Prof. Dr. Margono Soekarjo belum mencakup semua jenis lauk hewani yang terdapat dalam 
siklus menu 10 hari. Bobeng dan David (2012) menjelaskan bahwa sistem

HACCP harus didokumentasikan untuk menunjukkan bahwa sistem tersebut memang disusun dengan tepat dan berfungsi dengan benar. Dokumentasi yang disusun tim HACCP di Instalasi Gizi RSUD Prof. Dr. Margono Soekarjo berupa hard file dan soft file mengenai diagram alir proses pengolahan lauk hewani, daftar hazard atau bahaya yang diidentifikasi pada pengolahan lauk hewani, CCP pada bahan mentah dan proses pengolahan, serta tindakan koreksi apabila terjadi penyimpangan pada prosedur pengolahan.

\section{KESIMPULAN}

1. Identifikasi bahaya pada pengolahan lauk hewani dilakukan terhadap bahaya mikrobiologi, kimia dan fisik.

2. Penentuan CCP dilakukan menggunakan Diagram Pohon Keputusan atau Codex Decission Tree.

3. Penentuan batas kritis pada setiap CCP dilakukan dengan menyusun tahapan yang termasuk CCP kemudian menyusun parameter dan batas kritis setiap parameter.
4. Kegiatan verifikasi sistem dilakukan dengan monitoring rutin dan uji laboratorium.

5. Tindakan koreksi disusun berdasarkan tingkat resiko, namun belum ada tindakan koreksi yang pernah dilakukan.

6. Pencatatan dan dokumentasi HACCP belum mencakup semua jenis lauk hewani yang ada dalam siklus menu 10 hari di Instalasi Gizi RSUD Prof. Dr. Margono Soekarjo.

\section{SARAN}

1. Instalasi Gizi RSU D Prof. Dr. Margono Soekarjo melakukan sosialisasi menyeluruh kepada tenaga pengolah, pramusaji dan logistik yang terlibat dalam penyelenggaraan makanan mengenai penerapan sistem HACCP sebagai sistem keamanan dalam penyelenggaraan makanan.

2. Tim HACCP Instalasi Gizi RSUD Prof. Dr. Margono Soekarjo melakukan pencatatan dan pendokumentasian sistem HACCP secara menyeluruh, menyusun prosedur verifikasi secara tertulis dan menyusun jadwal monitoring khusus penerapan HACCP. 


\section{DAFTAR PUSTAKA}

Bobeng, B.J., dan David, B.D., 2012, HACCP Models for Quality Control of Entry Production in Hospital Foodservice System, Journal of the American Dietetic Association, 73 (5) : 524-529.
Cahyadi,M., 2011, Mikrobiologi Pangan Hewani (online), http://www.mcahyadi.staff.uns.ac.id/B =content_Artikel=Mikrobiologi_panga n.pdf, diakses pada 15 Agustus 2017.

Djarismawati, 2004, Pengetahuan dan Perilaku Penjamah Tentang Sanitasi Pengolahan Makanan pada Instalasi Gizi Rumah Sakit di Jakarta (online), http://www.media.litbang.depkes.go.id /index.php?option=content\&task=view \&id=15 \&Itemid=31, diakses 14 Maret 2017.

Hayes, P.R.., dan Forshytie, S.I., 2014, Food Hygiene, Microbiology and Hazard Analysis Critical Control Point (HACCP), Gaithesburg.

Jusniati, A.H., dan Burhanuddin, B., 2012, Manajemen Pengelolaan Makanan Di Rumah Sakit Umum Lanto Dg. Pasewang Kabupaten Jeneponto, Jurnal Kesehatan Masyarakat, 12 (4) : 122-128

Maria, M., 2004. Konsumsi dan persepsi pasien rawat inap terhadap makanan serta faktor-faktor yang mempengaruhi di RSUD Abdul Moelek Lampung, Skripsi, Departemen Gizi Masyarakat, Fakultas Ekologi Manusia Institut Pertanian Bogor, Bogor, 27-29.

Nene, A., 2012, Persepsi, Konsumsi dan Kontribusi Lauk Hewani Pada Pasien Rawat Inap di RSUD Cibinong, Skripsi, Departemen Gizi Masyarakat, Fakultas Ekologi Manusia Institut Pertanian Bogor, Bogor, 47-51.

Profil Kesehatan Kabupaten Banyumas, 2014, Jumlah Rumah Sakit di

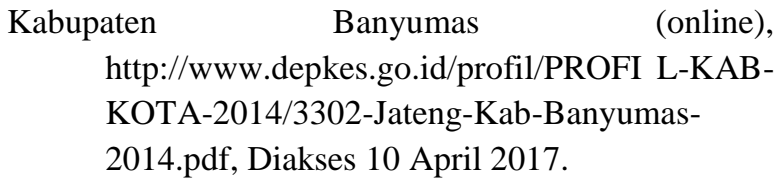
http://www.depkes.go.id/profil/PROFI L-KABKOTA-2014/3302-Jateng-Kab-Banyumas2014.pdf, Diakses 10 April 2017.

Puckett, R.P., 2004, Food Servive Manual For Health Care Institutions, 3rd ed, American Hospital
Association, San Francisco, 396-398.

Puspita, L.W., Yenny, P., dan Fatma, Z.N., 2010, Penerapan Hazard Analysis Critical Control Point (HACCP) terhadap Penurunan Bahaya Mikrobiologis Pada Makanan Khusus Anak Berbasis Hewani di Rumah Sakit

Umum Daerah Dr. Soedarso Pontianak, Jurnal Gizi Klinik, 7 (1) : 8-16.

Ratna, M.R., 2009, Evaluasi Manajemen Penyelenggaraan Makanan Institusi di Rumah Sakit Ortopedi Prof. Dr. Soeharso, Jurnal Studi Perpustakaan dan Informasi, 10 (2), (Abstrak).

Rauf, R., 2013, Penerapan Prinsipprinsip HACCP dalam Sistem

Penyelenggaraan Makanan, Graha Ilmu, Yogyakarta.

Thaheer,H., 2005, Sistem Manajemen HACCP (Hazard Analysis Critical Control Points), PT.Bumi Aksara, Jakarta.

Zulfana, I., dan Sudarmadji, 2008, HazardAnalysis Critical Control Point Pada Pengelolaan Makanan Pasien Rawat Inap di Rumah Sakit Islam Lumajang, Jurnal Kesehatan Lingkungan, 4 (2) : 57-68. 
